\title{
Psychic Suffering Nowadays: From Gadgets to the Consumed Subject*
}

\author{
Elizabeth Fátima Teodoro ${ }^{1, * *}$ (D), Alexandre Simões ${ }^{1}$ (D), \& Gesianni Amaral Gonçalves ${ }^{1}$ (D) \\ ${ }^{1}$ Universidade do Estado de Minas Gerais, Divinópolis, MG, Brasil
}

\begin{abstract}
This text aims to establish relationships between drugs and so-called gadgets from this social call to consumption whether they are objects in general, or drugs in particular. We carried out a bibliographic study using, mainly, books, articles, and dissertations referring to the subject with the intention to reach this objective. We also developed this research in three parts, which highlight the critical points of contemporary psychopathology. The first one deals with how the consumption of objects has become an object that consumes the subject. We then traced the legitimation of the subject "compressed" in the current discourse. Finally, we highlighted the gadgets and the new way of life for the contemporary people.
\end{abstract}

KEYWORDS: medicalization, object, psychodiagnosis, psychopathology, suffering

\section{Sofrimento Psíquico na Atualidade: Dos Gadgets ao Sujeito (Con)Sumido}

\begin{abstract}
RESUMO - Este texto tem por objetivo estabelecer as relações entre os medicamentos e os chamados gadgets a partir do chamado social ao consumo (tanto de objetos, em geral, quanto de fármacos, em particular). Para tanto, realizamos um estudo bibliográfico a partir de livros, artigos e dissertações referentes ao assunto. Assim, desenvolvemos esta investigação em três partes, as quais evidenciam os pontos críticos da psicopatologia contemporânea. A primeira delas aborda como o consumo de objetos transformou-se em objeto (con)sumido. Em seguida, rastreamos a legitimação do sujeito "comprimido" no discurso atual. Por fim, evidenciamos os gadgets e os novos modos de viver do contemporâneo.
\end{abstract}

PALAVRAS-CHAVE: medicalização, objeto, psicodiagnóstico, psicopatologia, sofrimento

I woke up flat on my back, everything was clear, but the sun just didn't make sense.

(Translated from Brazilian Portuguese) Paulo Leminski

\section{FROM AN EXCESS OF SPEECHTOTHE EXCESSES OF A SPEECH}

The current psychopathological debate highlights two important issues. The first concerns are the propensity of psychopathology for an excessive profusion of diagnostic classifications. Ultimately, these classifications imply a growing use of names and expressions (usually referred to as the word (disorder) to demarcate the broad field of

\footnotetext{
* E-mail: Support: Universidade do Estado de Minas Gerais, Programa interno de incentivo à pesquisa e à extensão - PROINPE; FAPEMIG

** elektraliz@yahoo.com.br

- Submetido: 07/04/2017; Revisado: 02/05/2018; Aceito: 02/05/2018.
} 
possibilities and manifestations of psychic suffering. We should also note that for each new disorder, it is suggested as a logical choice for intervention of symptoms, a composition of drugs that, in theory, would justify the ability to change levels and interaction between neurotransmitters (thus implying the organic causation hypothesis of psychic suffering).

The second very expressive question of psychopathology today alludes to the effects of the wide social injunction for satisfaction (immediate and excessive). This imperative (along the lines of will satisfy) in the face of its impossibilities and impasses, ends by, curiously, attaching the subject to a constant state of impotence or inadequacy to a social bond. In other words, the widespread expectation for satisfaction and success generates, in part, what it proposes, but leaves a continuing residue of dissatisfaction.

Both questions, in their clinical and social dimensions, point to the current impasses regarding the naming and characterization (well standardized in the so-called syndromes) of psychological distress. Thus, thinking about the phenomenon of medicalization of psychological suffering in contemporary times is fundamental for mental health professionals who are directly faced with such situations, either in the clinical or institutional context (collective and hospital health devices, legal scope, corporate world, penitentiary facilities, among others).

From this medicalization that expands to life itself and the behavior of individuals, resulting from the alienation of man in relation to himself and the world around him, it is possible to think of the abusive use of medicines as a response to social symptom, at the same time being subjective. This symptom allows us to map the aspects and processes that support this mode of existence of the subjects. This mapping advances, as we understand it, as we ask ourselves questions such as:

What is common between drug status (logic and conditions of use) and gadgets? Has the drugs taken over or has the gadget statutes taken over in contemporary society?

Within this scope, of a further investigation that follows is defined as the relationship between medicines and gadgets based on this social calling of consumption (both objects in general and medicines in particular). It can be inferred that these results may help in understanding the ways in dealing with the psychic suffering of today's society. Consequently, it is about guiding what is possible for mental health professionals, not to surrender to the discursive web of excessive and optimal performance without, however, failing to recognize the usefulness of restrained medicalization in many cases.

\section{FROM CONSUMPTION OF AN OBJECT TO THE OBJECT STATUS CONSUMED}

Many transformations in the field of mental health can be observed in contemporary situations, among them, the growing reflexes that are usually forthcoming from doctors are fundamental (Aguiar, 2004) and the unprecedented trends classify psychic suffering (Kyrillos Neto \& Calazans, 2012). Such events largely elapsed and the rise of the presence of the Diagnostic and Statistical Manual of Mental Disorders (DSM), as the main auxiliary (and influential) instrument in the diagnostic construction. This event has been promoting, or breaking Psychopathology with a classical psychiatry, which detects the detailed construction of psychopathological frameworks. In contrast, the DSM builds links with a so-called contemporary psychiatry, which uses a checklist like protocols to detect mental disorders from symptoms present in an individual's life.

This modus operandi is available not only to various mental health professionals (psychologists, psychiatrists, nurses, occupational therapists, general practitioners, and others), but it offers direct access to the general media, thus favoring that it should be understood by the general population. Thus, it is not necessary to find numerous websites, television programs, magazines, and others, providing information on "current illnesses" and the medicines used to treat illnesses. From a practical point of view, it is extremely common for patients to reach professionals working in the field of mental health, having already resorted in advance descriptions from forums and a number of websites, enjoying this repertoire and identifying their information as what it is. A self-service psychopathological. The search tool faithfully presents itself as a pain researcher.

Thus, we see the populations' unrestricted use of certain diagnostics that are conveyed by the media, promoting a consistent image that paints themselves as "the evil ones of the century". In this context, we see the status of problematic public health disorders such as depression, attention deficit hyperactivity disorder (ADHD), eating disorders, and bipolar affective disorder. Leader (2015) illustrated a depression-like situation in the 1980s, "the term bipolar became the label for the suffering of a new generation" (p. 11).

Regarding the DSM, it was found that its first version released in 1952, is perceived to differ in great variations in its logic and content from the DSM III in 1987, so that it passes a clinical description of the disease to a biological description that suspends any more precise etiopathogenic hypothesis, as well as a need for a non-reductionist clinical soap, as these manuals place themselves "an active psychiatric results service already experienced by the psychotropic market" (Quinet, 2002, p. 39).

Leader (2015), explaining a rise in bipolar disorder, traces the cogwheels of this machine known as the pharmaceutical industry: "It was just when the patents of the best-selling 
popular antidepressants began to expire in the mid-1990s that bipolar disorder suddenly became the beneficiary of the pharmaceutical industry's vast marketing budgets" (p. 11). And keeps going:

Web sites surfaced to help people diagnose, and articles in magazines and newspaper, supplements, all referring to bipolar disorder as if it were a reality - and almost all were funded, in part or in part, by the pharmaceutical industry. Internet questionnaires allow for self-diagnosis within minutes, and for many people it was as if their difficulties were finally answered. (Leader, 2015, p. 7)

These findings become susceptible to the veracity of the number of diagnostic categories, since they seem to be more with the service of pharmaceuticals that promote mental health.

Thus, both the demarcation of a diagnosis (currently based on the presentation of symptoms within a time interval) and the use of medications are used in common places in our daily lives for quick solutions. For Laurent (2002, p. 26), prior to this, "the panacea was used [psychoanalysts], and we didn't know it. Far from eliminating the amount of the medication - we had never left it - we covered ourselves as a whole".

We may wonder what the problem is, since, in theory, medicine is a medicine, therefore a biochemical that promotes healing and provides well-being. However, if we look at its etymological roots, it appears that such a word derives from the term phármakon. As Derrida (2005) points out, phármakon has ambiguous meaning, since it can mean both medicine and poison, thus there is a fine line between what can be beneficial or harmful. Therefore, from a closer perspective, one cannot make phármakon a panacea, just as its deleterious character cannot be disregarded:

There is no harmless remedy. Phármakon can never simply be beneficial. [...] The essence or beneficial virtue of a phármakon does not prevent it from being painful. [...] This painful enjoyment, linked to both illness and appeasement, is a phármakon in itself. It shares both good and evil, pleasant and unpleasant. Or rather, it is in their element that these oppositions are drawn. (Derrida, 2005, pp. 46-47)

Looking at the proliferation of diagnoses nowadays and still following Derrida's argument (2005), we call as a reference the myth of Theuth (presented in Plato's Phaedrus), in which the scripture is also seen as a phármakon. Thus, diagnostic writing presents itself as phármakon writing that, in a way, "are scratches on the surfaces and are the sliding signs , [...] which [...] would resurrect $[. .$.$] the supposed$ originality an event, at the cost of distancing the subject's presence from the utterance [speech] and, therefore, from the sense-restoring voice and revealing the true [symptom]". (Reis, 2013, p. 44, emphasis added).
Thus, we can present the diagnostic writing as an element of language fixation, so as to consider it, in the clinic, the death of the living (and plastic) speech that exposes the singular questions of each subject. This is because "the spoken language expresses the liveliness of an inner world [...], while the writing [...] launched in the world seems autonomous in its mechanic gesture of repetition" (Reis, 2013, p. 51). And as Laurent (2002, p. 27) states, "medicine has strange relationships with repetitions".

In contemporary times, we can perceive this equivalence of diagnosis to phármakon, believing that a dosage error of its use can cause the eclipse of the subject. In this sense, excess, a striking feature of our society, points to the problems of misuse of diagnoses.

In health, both diagnosis and medication become selfappropriations, transmuting into something to be swallowed, ingested, and consumed as a trait. In short, we are witnessing an anthropophagy of the drug as it carries another ambiguity, or rather a hybridity: it is both a molecule and an object of consumption.

In Lacan's theorizations (1964/1988) it is a driven activity that, instead of "devouring oneself", "consuming oneself", proposes "making oneself", "making oneself devoured", and "making oneself consumed" medicine. From this perspective, the drug insinuates itself as an object of libido, as Laurent (2002) points out. Like this:

Medicine is extracted from language by science, but it is the subject who reintroduces it into the structure. The subject of the drug, the one who accompanies him as his own shadow, reinserts the drug in the categories of what is being said. It is not a master, it is one of the master's signifiers of our civilization. The drug taken in the categories of what is being said. (Laurent, 2002, p. 30)

As we pointed out above, we can then say that in addition to the drug molecules at the biochemical level and the written words at the classificatory level of the manuals, both the drug and the diagnostics acquire a second value, the object of consumption. Thus, pills and diagnostics are evidenced as hybrids in our eminently consumerist society, guided hegemonically by scientific knowledge, which, in turn, is mostly at the service of capitalism and excellent performance.

Even more incisively, we can reason that diagnostics and medicines emerge "as an ordinary offer for naming the anguish that manifests itself [in daily life], mixed with the demand and the ideal of accelerating body and mind in the composition of a performative, efficient, and superintelligent being" (Santiago, 2013, p. 13). This transforms the consumed object (drug and diagnosis) into a supplement, that is, an object consumed to supply the failures that ultimately point to "the lack of".

The foundations of what will later be called capitalist discourse are briefly presented by Lacan (1969-1970 / 1992) in Seminar 17 - The Reverse of Psychoanalysis. In this discourse, the product object becomes what causes desire 
in the subject, so the subject begins to make social bond with this product / object of science. The object that from its consumption, would supply the lack of the subject (Quinet, 2009). This, to the point of in place of "the bond with the other, what one has is a subject who ties the diagnosis and the medication" (Couto, 2014, p. 91). The same author also points out that:

Seduced by the capitalist's discourse, the subject is not related to the field of the other, but to objects. Thus, instead of being entwined with the other, in an attempt to withstand the emptiness caused by the lack of, what one sees is a movement toward the object-product, which implies symptomatic configurations such as ADHD [and other diagnostic classifications]. ], where the subject succumbs to the drug. (Couto, 2014, p. 93)

In this sense, Laurent (2002, p. 31, emphasis added) states that "the medicine is lodged in the imagination by its effects of meaning [...] attributed [...] either by the subject, or by the person who prescribes it". Thus, one of these effects concerns "alienation or separation from the other." (Laurent, 2002, p. 31).

\section{FROM CONSUMPTIONTO THE LEGITIMATION OF THE "COMPRESSED" SUBJECT}

From the scenario described above, we find that psychic suffering has emptied itself of its meaning and dimension in contemporary society, since it seems to have become inhuman. Thus, the lack of this reference ends by favoring that the biologizing model tends to be hegemonic, as Ferreira says (n. d., p. 4), "giving meaning to human suffering is a fundamental axis of cultural organization". This is because the way we give meaning to suffering has always been closely related to the theoretical elaboration about this culture, as well as the way we start to act socially.

Thus, the space of subjectivity becomes a mere translation of everyday technical supports that, today, are expressed by excessive diagnostic classification, that is, serial naming of psychological distress, abuse of psychoactive drugs and a great need to neutralize what makes the subject talk.

To bet on a clinic centered on exclusivist psychopharmacological therapy is to legitimize the social discourse of the absence of pathos, of suffering, of what is not only a hindrance, but, above all, a factor of singularization of the subjects.

In these terms, in producing a mode of subjectivity of its own, contemporaneity drags psychic suffering in the form of malaise, the result of the marks of society. Such suffering is countered with drugs that compress the subject, thus enabling normalization of behaviors, attributing to the singular status of abnormality. Therefore, procedural rules are created from parameters that do not take into account the particularity of the subject's drive dynamics. This is because it is necessary to silence the voice that speaks in each subject so that the social discourse becomes the truth of each one.

Thus, the subject goes from a consumer to nonexistence, becoming itself an object (a piece easily replaced by the capitalist machine) that, in order not to be "discarded", consumes supplements that add attributes such as attention, tranquility, intelligence, speed, good humor, among others, endowing it with efficiency that does not happen in nature. In this case, the diagnoses also play a fundamental role, since, in many cases, they are used as justifications for an obsolescence, that is, they "explain" social discards. Given this situation, are medications and diagnostics not becoming gadgets in the contemporary? Aren't we witnessing the transformation of man himself into a system gadget?

\section{GADGETS AND THE NEW WAYS OF LIVING IN THE CONTEMPORARY}

Etymologically, the term gadget has an English origin and means appliance, device, or contraption, that is, a kind of technological device. Broadly and more freely, but rigorously, we may venture to say that a gadget is a piece of equipment or a device. According to Amaral (2009, without page), "complex devices, developed with the best technology available at the moment which aims to facilitate the tasks of those who use it. Equipment like iPhones, mp3 players and PDAs are considered gadgets". Gadgets are usually portable objects, inseparable from our bodies and our lives; tentacles of our way of existing, but easily discarded by bringing with them the DNA of programmed obsolescence.
Especially for psychoanalysis, gadgets that refers to "an object of short and rapid consumption" (Quinet, 2002, p. $35)$. As we have stated, such an object has because the result of capitalism, it is often disposable or easily exchangeable. According to Lustoza (2009, p. 47), these are "partial consumer objects that brings fleeting satisfaction and quickly becomes discarded". This association between the brilliance of the gadget and the waste is crucial, elevating it to an ephemeral kind of abject-object: "cars are offered as the driver's complement; Sports shoes are offered to consumers not for running, because running has been outdated: you have to fly" (Teixeira \& Silva Couto, 2010, p. 583). These are fleeting materializations, therefore, a well-known slogan of 
a large contemporary corporation that, in its widely exposed advertising videos whether on an old television, smart television or Youtube, suggests (or commands): no limits!

Following this logic of supply and consumption, we see a new kind of supply and demand rise, so drugs of all kinds of verity are offered, especially the psychotropic drugs, not only for disease prevention, but also for appearing excellence in this environment. Socially and professionally, it no longer makes sense to be good at your job, today you have to be a multiprofessional who gets to the brink of perfection. This because:

In the Capitalist's Discourse, gadgets, devices, are the most enjoyable objects (to) come in place of production and, with a fragile shield of significant logic, leaves the subject at the mercy of the objects. If we were talking before about an oral object that could be swallowed, assimilated, consumed, these new presentations of the object may stun the subject. (Rosa, 2010, p. 168)

This ambiguous relationship inherent in the gadget leads to the dissatisfaction as it encourages "an illusion of completion no longer with the making up of a pair, but with a connected and disconnectable partner within reach, [thereby producing] insatiable achievements. In their consumption demand" (Quinet, 2002, p. 35).

In the contemporary scene, therefore, we have the drug not only as a biochemical power, but as an object of consumption that, as a gadget, introduces a vicious circle by its use. To some extent, just as many of us are waiting for the launch of the latest smartphone model from a world-renowned brand, we look forward to the release of the latest mood stabilizer or the latest antidepressant also with anxiolytic effect.

We are in the midst of an effect of the Industrial Revolution, which, in its ties to a spectacular society (Débord, 2003) brings the illusion of an equal distribution of access to health, technologies and solutions:

Lacan points out that the Revolution did not bring about the improvement of the quality of life as intended, but created the illusion of equal distribution of enjoyment through access to products. Therefore, in the capitalist bond itself, we recognize the functioning of a consumer society in which workers become as consumable human material as products. (Teixeira \& Silva Couto, 2010, p. 584)
Following this reasoning, Rosa (2010, p. 168, emphasis added) states "where capitalist discourse prevails, it goes as if it were on wheels, that is, it goes too fast and thus' it consumes itself, it is consumed so well that it is consumed". And then differentiates between consumerism and consumerism to explain where the human being is:

If the former, points us to a system that favors overconsumption and indicates a tendency to overindulge, it is in the second term that the mode of enjoyment present in this tendency or impulse is explicit: consumption means the act of consuming (itself), the effect of consuming, and mortification [of the subject]. (Rosa, 2010, pp. 168-169, emphasis added)

As a result, "we have surrendered to this great compulsion that installs itself in a globalizing way, we are blind to look at ourselves and each other, replacing relationships with addictions, unbridled work and postmodern clutches" (Carvalho Campos, 2010, p. 4), with a dizzying speed and an increasingly relentless urgency, in which the new has been light years from the brand new.

However, this compulsive process has become so vicious that we witness in the contemporary the total dependence of the human beings on the so-called gadgets. Thus, what was made to be quickly discarded, today assumes the status of necessary and indispensable. We accept to change the model, the color or the formula, but we no longer know how to be without them. This is the case with the smartphone, as with diagnostics and medicines, as it is, according to Lasch (1987/1984, p. 22), “To characterize misleading consumer culture as a culture dominated by things. The consumer lives surrounded not only by things, but fantasies".

From this finding, the question arises: can diagnostics and medications still be considered contemporary gadgets or would it be worth thinking of them as prosthetics? Given that in medicine:

Prosthesis is considered the artificial part or device used to replace a limb, an organ, or part of it, as [...] cardiac prosthesis [...]. [However, more recently, besides the anatomical concept, there is a tendency to consider as a prosthesis also devices or devices for external use, intended to correct the deficient function of an organ, as in the case of hearing. (Rezende, 2006, p. 72)

\section{BY WAY OF CONCLUSION: MEDICINES AND LATUSAS}

In the contemporary scenario, what strikes the mind regarding the medicalization of psychic suffering is exactly that the subject is incessantly driven to enjoyment through the consumption of objects. What is at stake is not only the dimension of consumer objects, but the consumption of objects. Since he himself, the subject, has become an object of capitalism. 
To these objects, in this precise condition, Jacques Lacan named them exactly latusas (Lacan, 1969-1970 / 1992). Latusa, an uncommon and neological term, implies an object that would bring with it the promise of full satisfaction. Like a two-dimensional blade, it would penetrate everywhere, immerse itself in every crack and crevice, creating a medium in which we would live. Hence, in parallel, we have a lithosphere, a hydrosphere and an atmosphere that surrounds us and, in a way, demarcate our field of existence, we would have an alletosphere (from the Greek aletheia, meaning unveiled truth), therefore, containing the truth of our existence. The latusas would be, in Lacan's view, these objects that populate our environment and embody our truth and are found "on the floor of every corner, behind every window" (Lacan, 1969-1970 / 1992, p. 153) and sites. In their proliferation, in their multiplication, they are made to cause desire by subjecting us to an unbridled logic of consumption.
This would occur insofar as "the object is a function of discourses in action, it is a function of discourses that define civilization" (Soler, 1998, p. 167). That said, it remains to be noted that contemporary civilization "is the civilization of science and the objects it generates" (p. 167).

It is under this regime of truth and, at the same time, within this atmosphere that we can most finely understand the trends and challenges present in the fields of psychopathology and mental health. Passing through the objects of consumption, the consumption of objects, reading them from the perspective of either gadgets or prosthetics or latusas, we take here the inviting words of Deleuze who, in his already classic article on societies of control, under the same terrain A critic (albeit from other references) proposes: "It is not necessary to fear or wait, but to seek new weapons" (Deleuze, 1992, p. 220).

\section{REFERENCES}

Aguiar, A. A. (2004). A psiquiatria no divã: Entre as ciências da vida e a medicalização da existência. Rio de Janeiro: Relume Dumará.

Amaral, F. E. (2009). O que é Gadget? E Widget, é a mesma coisa? Retrieved from https://www.tecmundo.com.br/1959-o-que-egadget-e-widget-e-a-mesma-coisa-.htm

Carvalho Campos, M. das G. de. (2010, novembro 30). Axiodrama: Uma possibilidade de ressignificar o tempo e a impaciência na pós-modernidade. $17^{\circ}$ Congresso brasileiro de Psicodrama. $1^{\circ}$ Congresso latino-americano de psicoterapia de grupo e processos grupais. Águas de Lindóia, São Paulo, Brasil. Retrieved from www.febrap.org.br/.../AXIODRAMA\%20 UMA\%20POSSIBILIDADE\%20DE\%20RE...

Couto, D. P. do. (2014). O sujeito-criança: a constituição subjetiva graças aos pais e apesar deles (Master's Thesis). Programa de Mestrado em Psicologia, Universidade Federal de São João del-Rei, São João del-Rei, MG, Brasil.

Débord, G. (2003). A sociedade do espetáculo. Ebooks Brasil.

Deleuze, G. (1992). Conversações. Rio de Janeiro: Editora 34.

Derrida, J. (2005). A farmácia de Platão. (R. da Costa, Trans.). São Paulo: Iluminuras.

Ferreira, J. (n. d.). Sobre o sofrimento na contemporaneidade: A medicalização do sofrimento na contemporaneidade: o caso da melancolia. $36^{\circ}$ Encontro anual da ANPOCS - GT24 - O pluralismo na teoria social contemporânea. Águas de Lindóia, em São Paulo, Brasil. Retrieved from http://www.anpocs. org/index.php/papers-36-encontro/gt-2/gt24-2/8115-sobre-osofrimento-na-contemporaneidade/file

Kyrillos Neto, F., \& Calazans, R. (Orgs.). (2012). Psicopatologia em debate: Controvérsias sobre os DSMs. Barbacena: EdUEMG.

Lacan, J. (1988). O seminário, livro 11: os quatro conceitos fundamentais da psicanálise. Rio de Janeiro: Jorge Zahar Editor. (Originally published in 1964)
Lacan, J. (1992). O seminário. Livro 17: o avesso da Psicanálise. Rio de janeiro: Jorge Zahar. (Originally published in 19691970)

Laurent, É. (2002). Como engolir a pílula?. Clique, $\mathrm{n}^{\circ} 1$, abril de 2002 - Palavras e pílulas. A psicanálise na era dos medicamentos, 24-35.

Leader, D. (2015). Simplesmente bipolar. Rio de Janeiro: Zahar.

Lustoza, R. Z. (2009). O discurso capitalista de Marx a Lacan: Algumas consequências para o laço social. Ágora, 12(1), 4152.

Quinet, A. (2002). A ciência psiquiátrica nos discursos da contemporaneidade. In R. Lima, M. A. Peixoto, A. Quinet, $\&$ N. Viana (Eds.), Psicanálise, capitalismo e cotidiano (pp. 32-40). Goiás: Germinal.

Quinet, A. (2009). Discurso como laço social. In Psicose e laço social (2nd ed., pp. 15-46). Rio de Janeiro: Jorge Zahar.

Reis, D. (2013). Nos jardins secretos da escritura: Platão e(m) Derrida. Ensaios Filosóficos, 8, 44-53.

Rezende, J. M. de. (2006). Prótese, próstese e órtese. Revista de Patologia Tropical, 35(1), 71-72.

Rosa, M. (2010). Jacques Lacan e a clínica do consumo. Psicologia Clínica, 22(1), 157-171.

Santiago, A. L. (2013). A psicanálise do hiperativo e do desatento... com Lacan. In A. L. Santigo \& M. Mezêncio (Eds.), $A$ psicanálise do hiperativo e do desatento... com Lacan. (pp. 9-24). Belo Horizonte, Scriptum.

Soler, C. (1998). O sintoma na civilização: o psicanalista e as latusas. Curinga, 11, 164-174.

Teixeira, V. L., \& Silva Couto, L. F. (2010). A cultura do consumo: Uma leitura psicanalítica lacaniana. Psicologia em Estudo, 15(3), 583-591. 